\title{
The Implementation of the Lesson Study in Basic Teacher Education: A Research Review
}

\author{
Eurydice-Maria Kanellopoulou ${ }^{1} \&$ Maria Darra ${ }^{1}$ \\ ${ }^{1}$ Department of Primary School Education, University of the Aegean, Rhodes, Greece \\ Correspondence: Department of Primary School Education, University of the Aegean, Rhodes, Greece. \\ E-mail: evikanell@gmail.com
}

Received: May 25, 2019

doi:10.5539/hes.v9n3p65

\author{
Accepted: June 14, 2019 Online Published: July 11, 2019 \\ URL: https://doi.org/10.5539/hes.v9n3p65
}

\begin{abstract}
The lesson study is a teaching practice that was first applied to the educational system of Japan. It is a form of classroom research in which teachers cooperatively plan, teach, observe and share the results in a class lesson. The purpose of this study is to review the effectiveness of the implementation of the lesson study in basic teacher education through the review of 29 empirical researches conducted both in Greece and the world over the past decade (2008-2018). In particular, a. the contribution of the lesson study in mobilizing and improving the performance of preservice teachers and $b$. the attitudes and beliefs of preservice teachers and their educators on the use of this particular teaching approach. The results of the research revealed that lesson study contributes to mobilizing preservice teachers, improving their performance, and developing positive attitudes and beliefs of learners and trainers regarding its use in higher education. There is also a need for further research on the implementation of the lesson study in higher education, mainly in Greece, compared to the international field.
\end{abstract}

Keywords: lesson study, professional development, basic teacher education, motivation, performance, attitudes

\section{Introduction}

Improving the education provided, presupposes the continuous professional development of teachers, starting with their university education. The continuous upgrading of the theoretical curricula and their practical implementation in the classrooms is one of the main objectives of higher education (Rekalidou, Karadimitriou, \& Moumoulidou, 2014). Several researchers point to the gap between theory and practice during the training of future teachers and claim that it is necessary to improve their theoretical and practical training (Juhler, 2018). They also emphasize the importance of lifelong teacher education (Saito, 2012).

In order to improve the education of future teachers, several researchers highlight the importance of programs of constructive approach, as constructivism is seen as a more natural and productive framework for their education and they realize the positive impact on their perceptions of the student and for their own teaching skills, increasing confidence and improving their teaching practice in classrooms (Gordon \& Debus, 2002; Dejene, Bishaw, \& Dagnew, 2018).

The design of training programs for preservice teachers, promoting their knowledge and skills, is a constant challenge in higher education (Hiebert, Morris, \& Glass, 2003; Wessels, 2018). Also, many researchers point out the importance of co-operation between trainees as well as between trainer and trainees, the value of interaction within the group, and the importance of reflection in their education (Rekalidou et al., 2014). Reflection enables preservice teachers to collect information, process them within the group, and use them appropriately during their teaching practice. Thus, programs that enable future teachers to actively participate in the educational process and to work with their colleagues are more effective (Saito, 2012).

An effective program of professional development of future teachers, which is based on constructivism and can narrow the gap between theory and practice is a lesson study (Wessels, 2018; Rekalidou et al., 2014). The review of international and Greek literature shows that several studies have explored the contribution of the lesson study to improving student learning and professional development (McDowell, 2010; Levy \& Hourigan, 2016; Dania, Voutsina, \& Moumouri, 2013) as well as to the formation of more positive attitudes and beliefs of participating preservice teachers (Carroll, 2013; Post \& Varoz, 2008; Juhler, 2018). In addition, several studies have studied the advantages of the lesson study, while fewer have dealt with the difficulties in implementing it (Hamzeh, 2014; 
Lucas, 2014; Burroughs \& Luebeck, 2010) and even fewer researches have explored the conditions for its effective implementation in higher education (Molina, 2012; McDowell, 2010).

The purpose of this study is to investigate the contribution of the lesson study to improving the effectiveness of the internship of the preservice teachers by analyzing the relevant researches carried out during the last decade to draw useful conclusions, identify any gaps that may exist and make suggestions for further research.

\section{Lesson Study: Theoretical Approach}

The lesson study is a teaching practice that was first applied to the educational system of Japan. It is a form of classroom research where teachers collaborate to design, teach, monitor and share the results in a class lesson (Espinosa, Datukan, Butron, \& Tameta, 2018). The lesson study, which is based on the pedagogical theory of social constructivism, fosters dialogue among teachers, supports participatory learning and educational reflection, contributing to the improvement of teaching for the benefit of learners, but also in the professional support of the teachers themselves (Giannakidou, Gioftsali, \&Tzioras, 2013).

The lesson study process presupposes the co-operation of a team of teachers of the same specialty to design and implement a research lesson in 10-15 hours over three to four weeks (Fernandez, 2002). It includes the following stages: a) setting goals, b) planning the research lesson, c) teaching, observing and data collecting of the research lesson, d) evaluation - feedback and re-teaching, and e) reflection, formulation and sharing final results (Stepanek, Appel, Leong, Mangan, \& Mitchell, 2007).

More specifically, teachers of the same specialty of a school who teach the same lesson through constructive dialogue and free exchange of views cooperate voluntarily and equally to carry out the research lesson by formulating a detailed teaching plan that a member of the group will implement to the class (Stepanek et al., 2007). With the individual experiences of participating teachers, their lesson is expected to be rich and well structured (Espinosa et al., 2018).

In addition, at this stage the teaching activities, the means and the techniques to be used are described in detail, while at the same time evaluating and commenting on the possible reactions and responses of the students to each of them (Dania et al., 2013).

The observation of the way the research lesson is taught, the processing of the data related to the learning of learners accumulated during the course, as well as the evaluation - feedback and reflection, contribute significantly to the improvement of the lesson as well as to the professional development of teachers (Stepanek et al., 2007). Reflection and observation are key components of the lesson study, which contribute to the improvement of teaching (Lewis \& Tsuchida 1998; Wessels, 2018). The findings from the implementation of the research lesson are then communicated so other teachers interested in implementing the lesson study so as to get data and apply them (Murata \& Pothen, 2011).

The lesson study enhances the continuous learning of learners and teachers. By improving their professional knowledge and skills and combining theoretical and practical learning, the latter provide high quality teaching to learners, giving them opportunities for meaningful acquisition of knowledge (Nishimura 2016; Wessels, 2018). Also, trainees cultivate their critical thinking and ability through the contribution of team and collaborative method that is applied to the lesson study and develop important skills that improve their learning (Darling-Hammond \& Richardson, 2009).

\section{Purpose and Research Questions}

The purpose of the present study is to investigate the effectiveness of the lesson study on the continuous improvement of the basic education of preservice teachers in higher education, through the analysis of 24 researches from Greece and internationally which took place during the last decade (2008-2018). In particular, this study investigates: a. the contribution of the lesson study in mobilizing preservice teachers to achieve specific goals and to improve their performance $b$. the attitudes and beliefs of preservice teachers and their educators in teaching the lessons using the particular teaching approach. Indicative questions put to the investigation and which the research will attempt to answer are the following:

1st: Is there a mobilization of preservice teachers in achieving specific goals and improving their performance as a result of implementing the lesson study?

2nd: What are the attitudes and beliefs of the preservice teachers and their educators regarding the contribution of the lesson study to improving the effectiveness of internship?

\section{Research Methodology}

For the purposes of this study, the review was conducted on the following search bases: google scholar, ERIC, 
Taylor \& Francis. It is worth mentioning that the choice of these search bases was based on the accessibility criterion and therefore this choice is a limitation of the present literature review. For the purposes of this review, research papers published during the last decade (2008 to 2018) in scientific journals on the implementation of the lesson study on basic teacher education at university were selected, reported data for the methodological planning that followed (type of research, tools, sample) as well as the main results of the lesson study implementation in the educational context in which they were implemented. The results that emerged from the analysis of the above data are presented in the corresponding chapter of the study.

Research was conducted in accordance with the following criteria listed in Table 1.

Table 1. Selection criteria for researches

$$
\text { Selection criteria for researches }
$$

\begin{tabular}{ll}
\hline Research questions & $\begin{array}{l}\text { (a) Does the lesson study contribute in mobilizing preservice teachers to achieve specific } \\
\text { objectives and improve their performance? } \\
\text { (b) What are the attitudes and beliefs of the preservice teachers and their educators } \\
\text { regarding the contribution of the lesson study to improving the effectiveness of internship? }\end{array}$ \\
$\begin{array}{ll}\text { Geographical } & \text { Universal } \\
\text { distribution } & \\
\text { Year of publication } & \begin{array}{l}2008-2018 \\
\text { Language }\end{array} \\
\text { Type of research } & \text { Gmpirical }\end{array}$ \\
\hline
\end{tabular}

Figure 1 shows the flow diagram of the methodology followed in this bibliographic review.

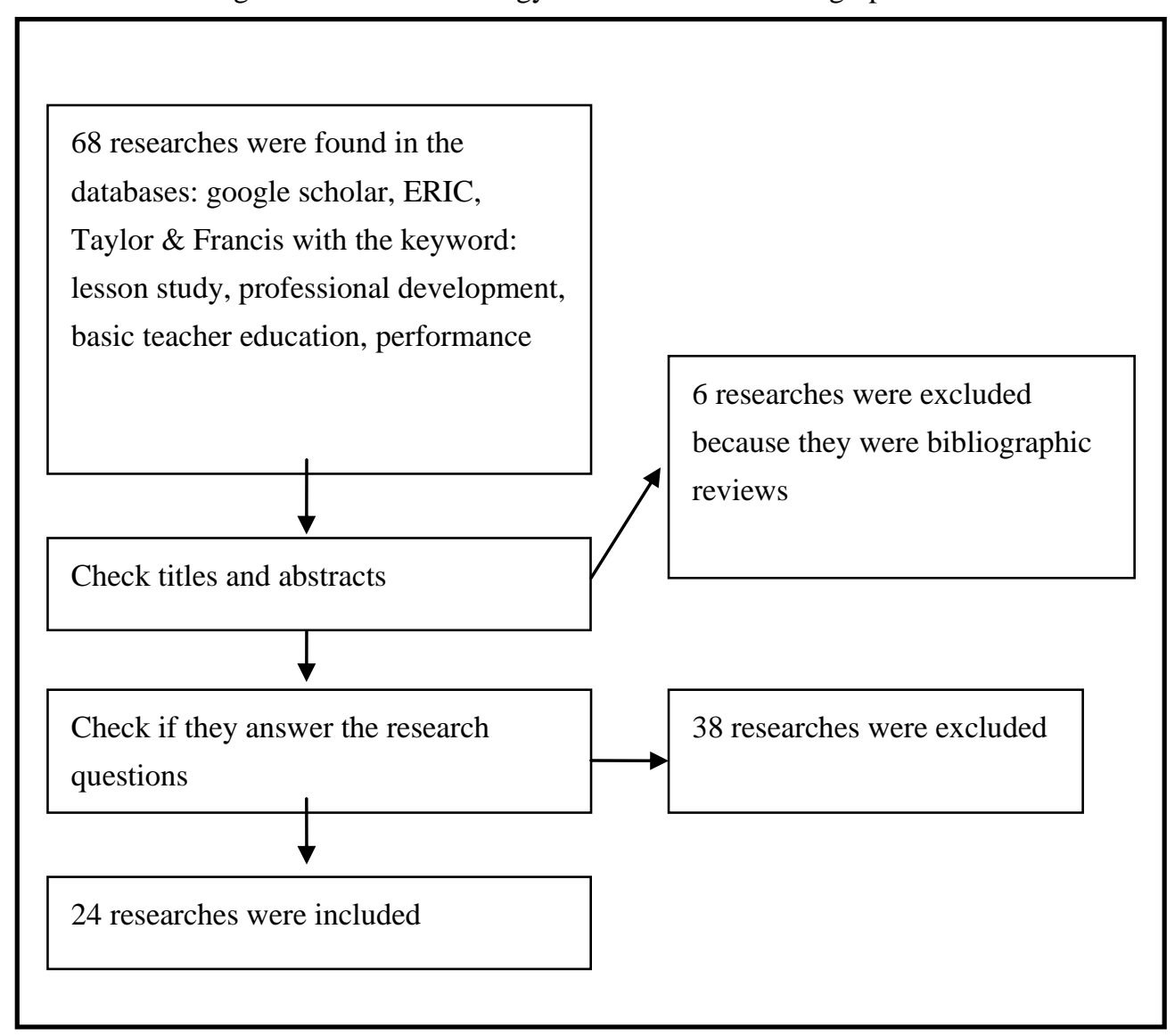

Figure 1. Flow diagram of the methodology

\section{Results of the Research}

The results of the research contain data on the number of studies researched per year, their country of origin, the type and the size of the sample of surveys. Also, the results of this research are presented in tables per research 
question.

Figure 2 shows the number of researches per year.

\section{The number of researches per year}

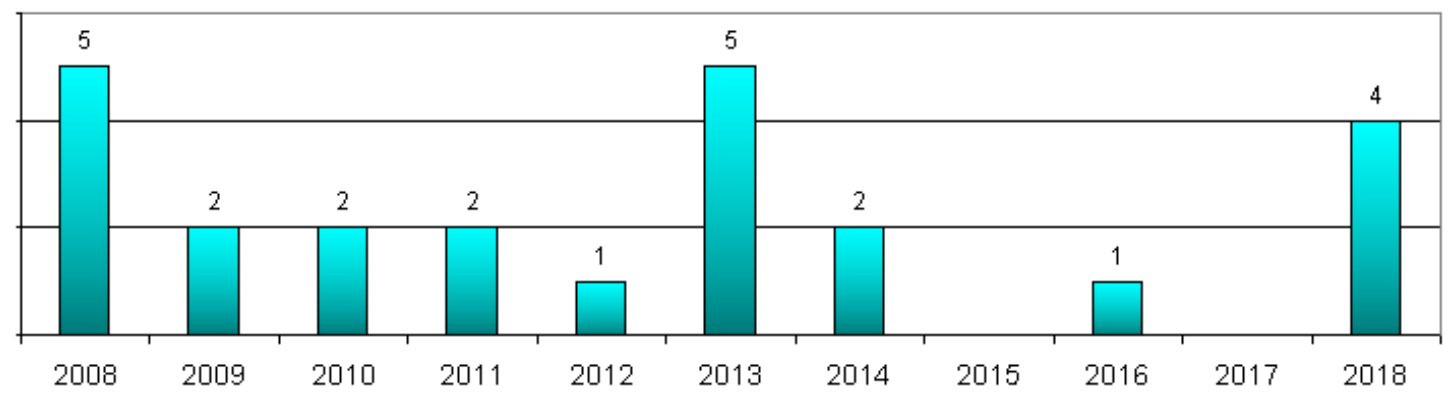

Figure 2. Number of researches per year

Figure 3 shows the number of researches in Greece and internationally.
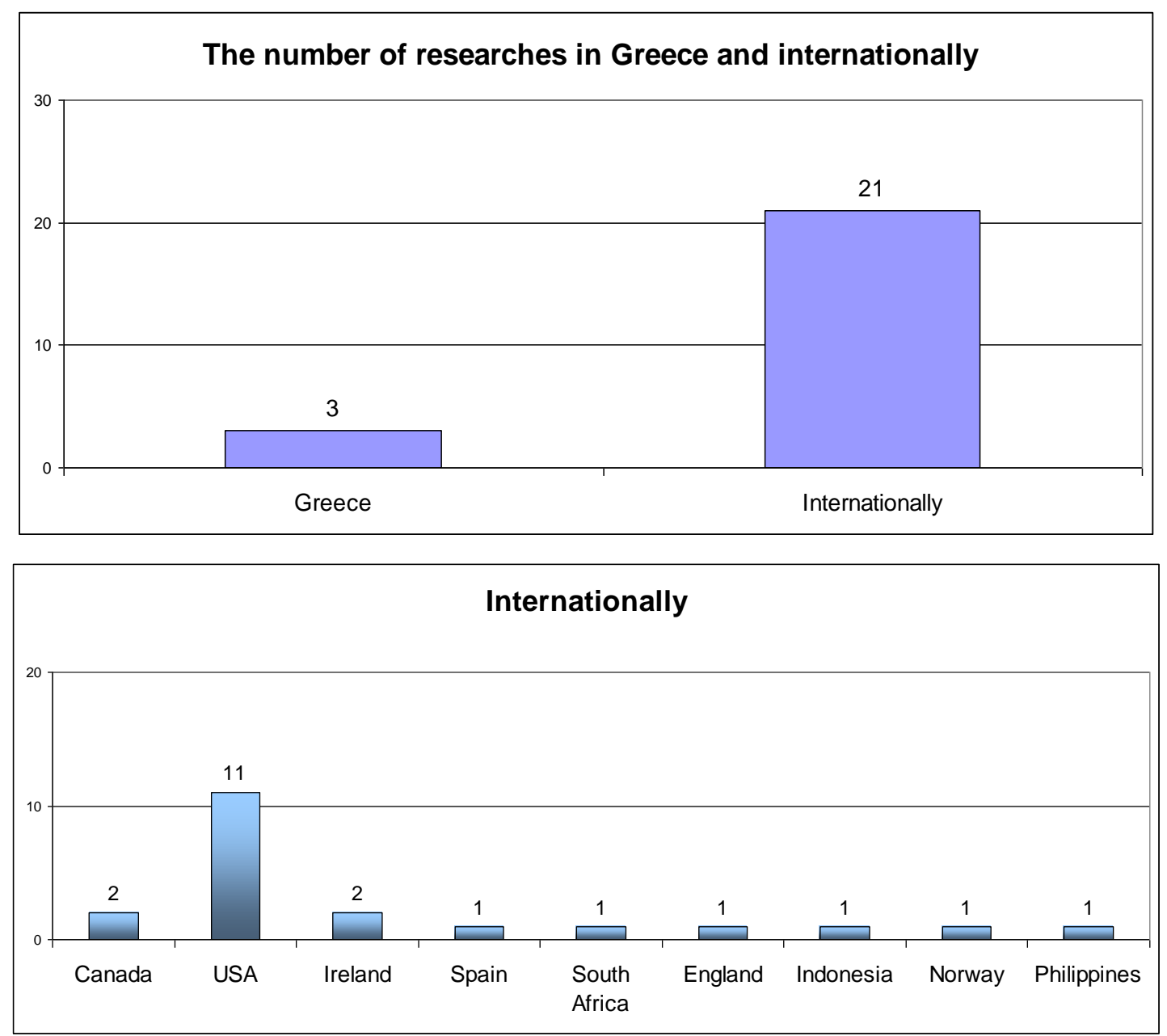

Figure 3. Number of researches in Greece and internationally 
Figure 4 shows the number of researches per type.

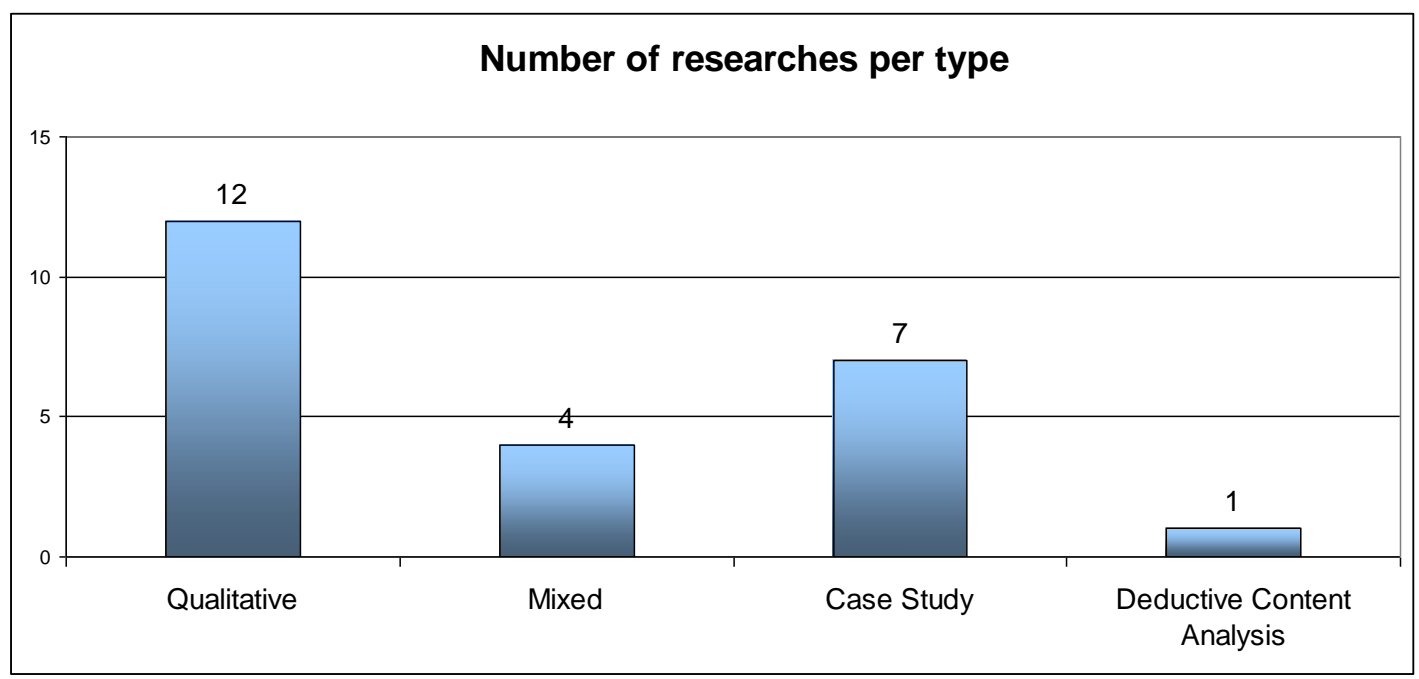

Figure 4. Number of researches per type

1st Research question: Is there a mobilization of preservice teachers in achieving specific goals and improving their performance as a result of implementing the lesson study?

Table 2 summarizes the main findings of the studies investigated on the contribution of the lesson study to the mobilization of preservice teachers in achieving specific goals and improving their performance in higher education.

Table 2. Contribution of the lesson study to the mobilization of preservice teachers in achieving specific goals and improving their performance in higher education

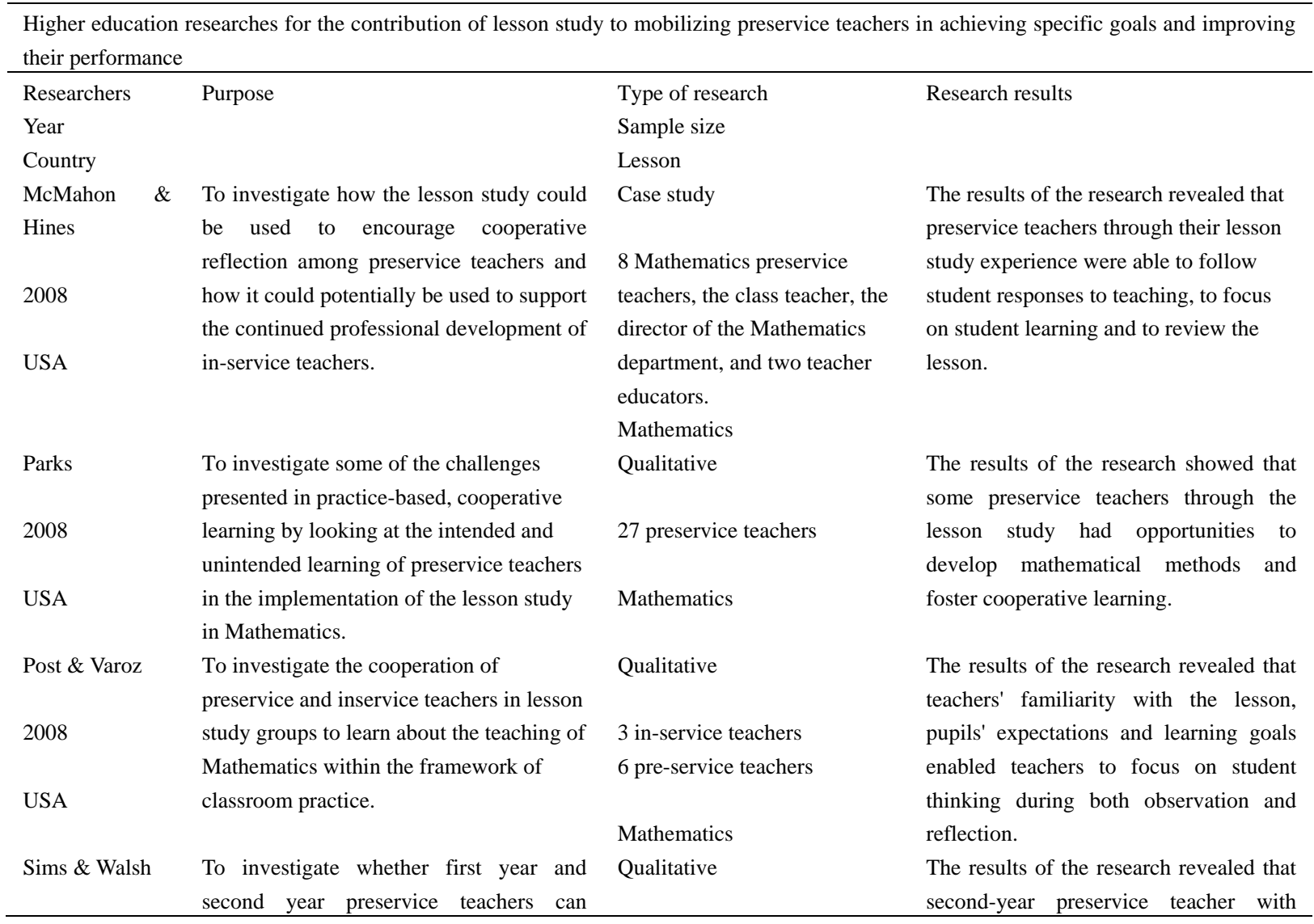




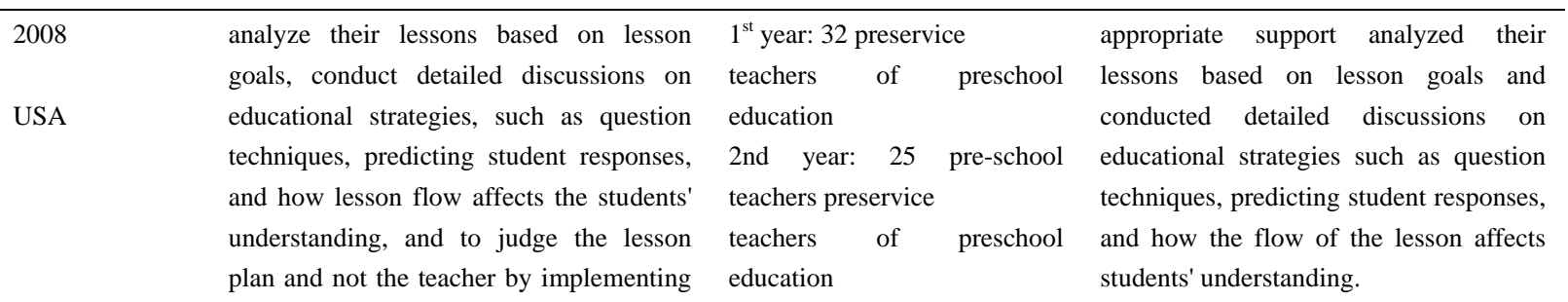

Chassels \& $\quad \begin{aligned} & \text { To investigate the benefits and challenges } \\ & \text { of participating teacher candidates in the } \\ & \text { Melville }\end{aligned}$
lesson study.

2009

Canada

Matthews, Hlas To investigate the contribution of lesson \& Finken study and lesson design to four columns with preservice teachers focusing on

Fernandez

USA

Pongsason, Akerson, Rogers \&Weiland 2011

USA

Molina student-centered learning and the usefulness of colleagues' collaboration.

\section{Qualitative}

60 teacher candidates

20 field practicum associate teachers

the pre - service

instructor and

first author

Mathematics of elementary

school

Qualitative

3 preservice teachers

1 supervisor professor

Mathematics

Case study

18 preservise

teachers

Mathematics

Case study

6 preservice teachers

Science

Mixed

103 participants

Mathematics
The lesson study provides opportunities for teacher candidates to create professional learning communities, to deepen the understanding of the curriculum and pedagogy, and to develop critical observation, analysis and reflection habits.

The lesson study contributes to the professional development of teachers. Preservice teachers have confirmed that the design of the four columns (in the first column, the teacher lists the traditional sequence of activities together with the previously planned questions, in the second column the possible answers to these questions are noted, in the third column, the teacher suggests ways in which he/she could respond to the reactions and actions of the students in the particular lesson and the fourth column is intended for the informal and continuous assessment of the students' teaching) and the lesson study helped them to focus more on students' thinking according to the approach of teaching, planning and assessment.

The results of the research revealed that pre- and post-lesson projects showed an increased knowledge of the participants 'teaching, in line with the great goal of the students' learning process.

The results of the research revealed that the lesson study may have some influence on the pedagogical content of preservice teachers to teach the nature of Science.

The results of the research revealed that students were mobilized in achieving specific goals and improved their performance with the help of the mentor. 


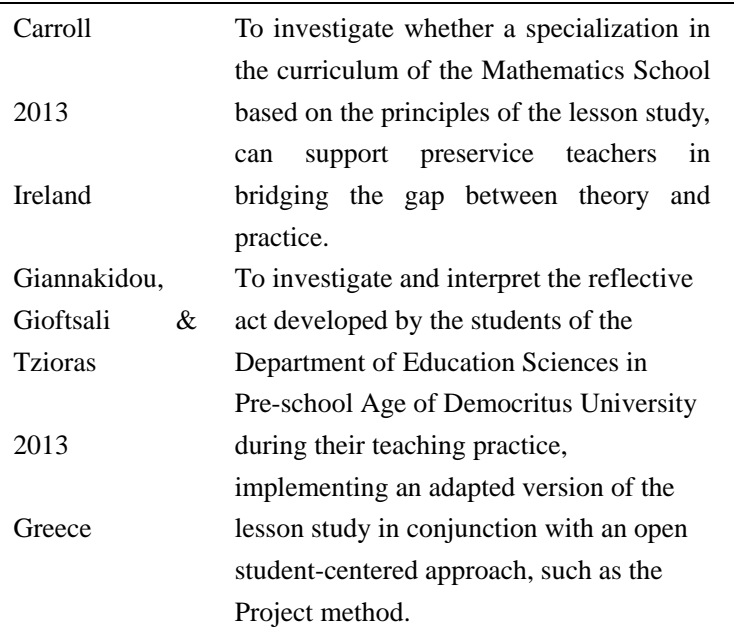

Hamzeh

2014

Canada

Rekalidou,

Karadimitriou

\&

Moumoulidou,

2014

Greece

Leavy

Hourigan

2016

Ireland

Angelini

Alvarez

2018

Spain

Juhler

Norway

Wessels enables preservice teachers to improve their teaching through exploratory learning. Also, if teachers' beliefs about their self-efficacy are related to their experience of lesson study, and if they are urged to cooperate with each other.

Finally their attitudes and perceptions about the lesson study in the field of

Science are examined.

To investigate the processes of collaboration, reflection and feedback from the perspective of students and supervisors who have implemented the lesson study to students' teaching practice.

\& To explore the development of pedagogical knowledge of the content of preservice teachers stemming from the involvement and reflection of teaching primary Mathematics in a lesson study structure.

\& To examine the perceptions of preservice teachers who used the lesson study for a five-week teaching at school and to analyze their perceptions of how the lesson study influenced classroom teaching in preschool and primary education.

The study investigates the problem of the difference between theory and practice by introducing the lesson study and the representation of content as an intervention in the practical training of teachers.
Qualitative

25 participants

Mathematics

Case study

2 groups of 8 students

1 supervisor

Project

creating a Greek-Turkish

dictionary

Mixed

The results of the research revealed that the participating students were mobilized in achieving specific goals and improved their performance.

The results of the research revealed that students also showed samples of technocratic and interpretative reflection before and after the act. At the same time, students' critical reflection was developed, only in individual exhibitions submitted after the completion of their classroom practice.

One factor that favored the development of reflective thinking of sample students was the cooperative character of the model and the process of collective feedback.

The results of the research highlighted the mobilization of participants in

48 participants

Natural Sciences (Biology, Physics) improving their teaching. Participants correlated their improved self-efficacy with the lesson study process.

Mixed

127 students 5 supervisors

Teaching Practice

Case study

25

preservice teachers

primary education

Mathematics

Qualitative

12 undergraduate preservice teachers

English as a foreign language

Deductive content analysis

7 students

7 preservice teachers

2 mentors

Physics
The results of the research revealed that cooperation between students and students supervisors positively influenced the performance of students.

The results of the research revealed that lesson study promoted effective learning and the development of knowledge amongst preservice teachers.

The results of the research have revealed empirical knowledge of how the lesson study reinforced preservice teachers' education classes and lesson design skills.

During the intervention, the preservice teachers focused more on the goals of teaching, students and their learning, on the better representation of specific content and on the specific assessment compared to the current state of the practice. The results of the research revealed that 


\begin{tabular}{|c|c|c|c|}
\hline 2018 & $\begin{array}{l}\text { teachers on their own and the following } \\
\text { research lessons in order to improve the } \\
\text { structure and development of reflective }\end{array}$ & $\begin{array}{l}3 \text { preservice teachers } \\
56 \text { observers }\end{array}$ & $\begin{array}{l}\text { teachers moved to higher levels with a } \\
\text { greater focus on mathematical logic and } \\
\text { student thinking. }\end{array}$ \\
\hline South Africa & $\begin{array}{l}\text { mathematical practice in an undergraduate } \\
\text { teacher training program. }\end{array}$ & Mathematics & \\
\hline
\end{tabular}

2nd Research question: What are the attitudes and beliefs of the preservice teachers and their educators regarding the contribution of the lesson study to improving the effectiveness of internship?

Table 3 summarizes the main findings of the investigations examined regarding the contribution of the lesson study to the formation of positive beliefs and attitudes of preservice teachers and their educators regarding its contribution to improving the effectiveness of internship.

Table 3. Contribution of the lesson study to the formation of positive beliefs and attitudes of preservice teachers and their educators

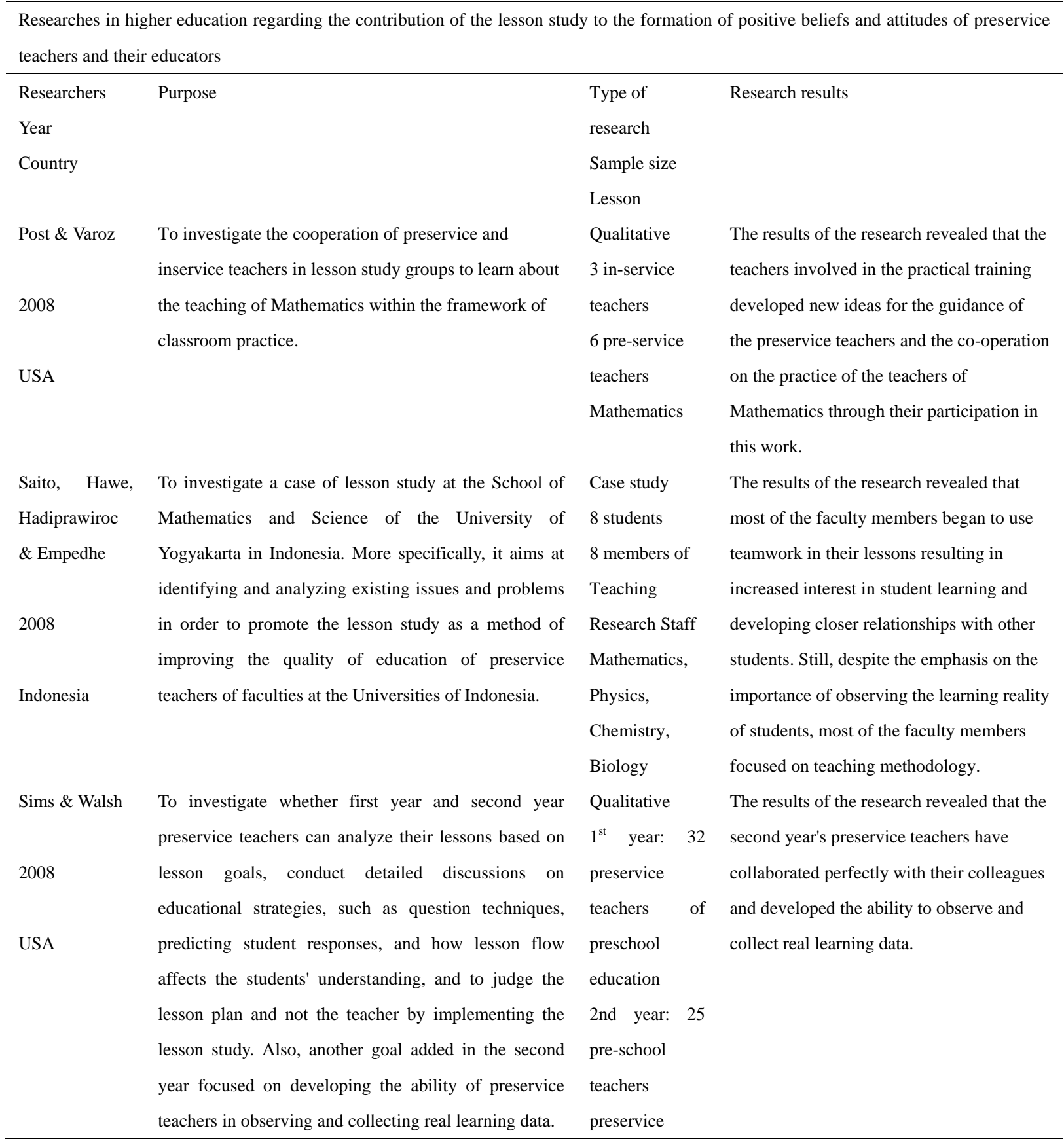




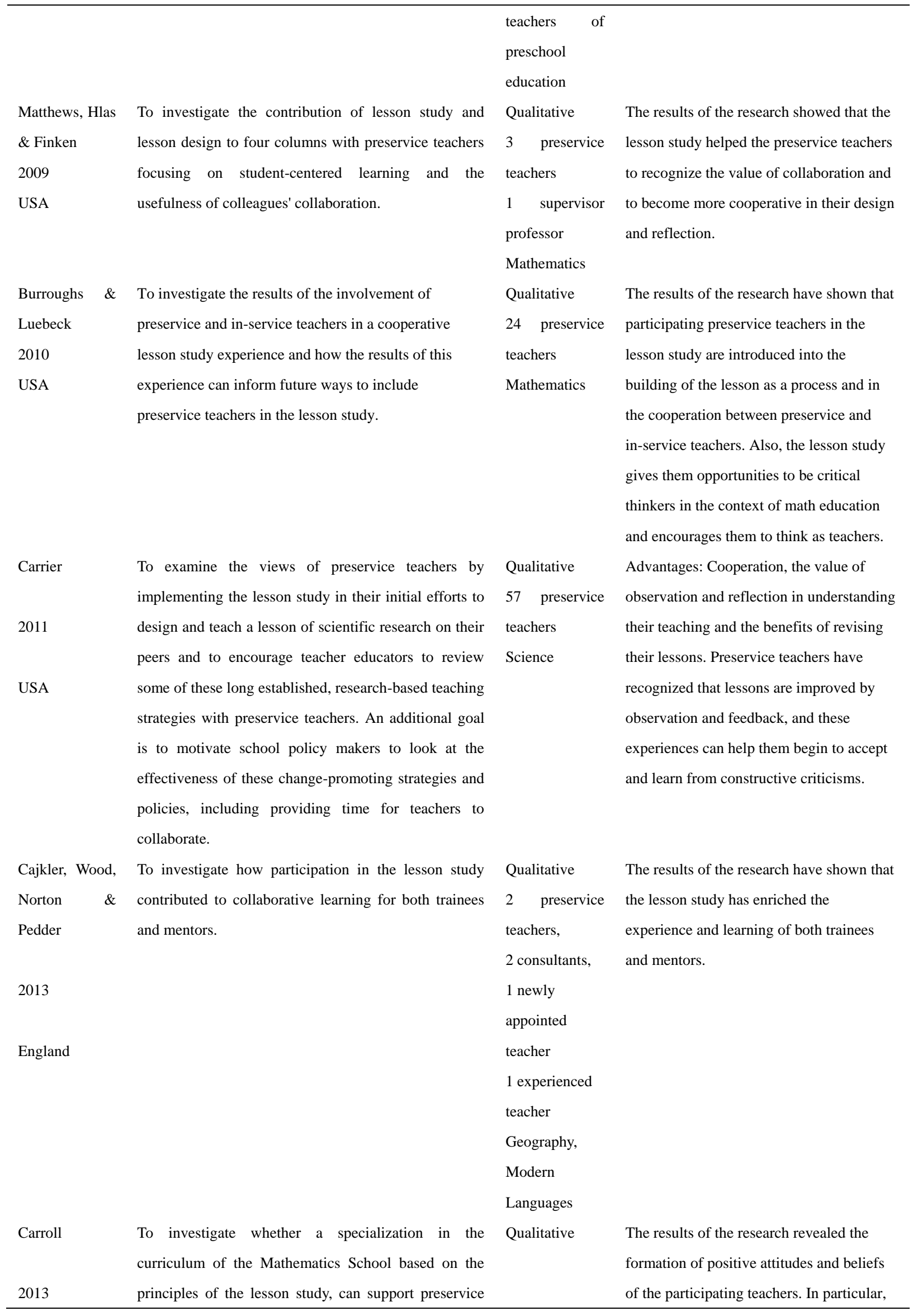


teachers in bridging the gap between theory and

Ireland practice

Dania,
Voutsina $\quad \& \quad \begin{aligned} & \text { To present the model of the lesson study, as } \\ & \text { Moumouri }\end{aligned}$
the Department of Physical Education and Sport
2013
Science, National and Kapodistrian University of
Athens. The main aim was to highlight the unseen
aspects of physics lessons teaching and through it the
identification of the elements that influence the
identification of an effective lesson.
To investigate the outcome of the lesson study in
collaborative knowledge building and teacher reflection
as well as thoughts, feelings and actions in relation to
USA

Leavy \& To explore the development of pedagogical knowledge

Hourigan

2016

Ireland

Espinoza, To investigate preservice teachers' perceptions of using

Datukan, the lesson study as a framework for teaching High

Burton \& School Chemistry. In particular, this study investigates

Tameta

Philippines

in Chemistry compared to traditional teaching as well

as the advantages and disadvantages of this framework.

Finally, if they suggest that this framework will be used
25 participants

Mathematics

Qualitative

Physical

Education

Mixed

5 participants

Language

Mathematics

Case study

25

preservice

teachers

primary

education

Mathematics

Case study

30 young

Chemistry

preservice

teachers

in primary schools. they developed confidence in the use of constructive teaching approaches, improved the skills to ask questions and collaborate, and began to reflect more openly and honestly in their lessons. They developed the knowledge and practice of teaching.

The results found that the implementation of the lesson study has positively influenced the experiences of the students from their practical training.

Increase the effectiveness of the participants' teaching. Increased collaboration and in-depth reflection. Positive changes in teaching practices and focus on learning from practice.

The results of the research revealed that the lesson study was successful in activating the development of pedagogical knowledge of the content of the preservice teachers.

The results of the research have shown that the lesson study can help improve teachers' teaching abilities and lead students to greater achievements in the Chemistry lesson.

\section{Discussion of Research Results}

Overall, the average of surveys per year from 2008 to 2018 is 2.4. Most researches have been conducted internationally and the largest number has been conducted in the US $(n=11)$, while fewer in other countries. In Greece, a minimum number of surveys $(n=3)$ compared with the international area $(n=21)$ has been identified.

Regarding the contribution of the lesson study to the mobilization of preservice teachers to achieve specific goals and to improve their performance in higher education (first research question) from the results of this research it follows that the lesson study contributes to the mobilization of the preservice teachers in achieving specific goals 
and improving their performance in higher education internationally in Mathematics courses (McMahon \& Hines, 2008; Parks, 2008; Post \& Varoz, 2008; Chassels \& Melville, 2009; Matthews et al., 2009; Fernandez, 2010; Molina, 2012; Carroll, 2013; Leavy \& Hourigan, 2016; Wessels, 2018), Science (Pongsason et al., 2011), Physics (Hamzeh, 2014; Juhler, 2018), Biology (Hamzeh, 2014) and teaching English as a foreign language (Angelini \& Alvarez, 2018). In Greece, the lesson study was investigated for the mobilization of preservice teachers as part of their Teaching Practice (Ralkalidou et al., 2014) and the Project method (Giannakidou et al., 2013). Mobilizing them to achieve specific goals and improve their performance is achieved through their lesson study experience, which enables them to analyze their lessons based on the learning objectives they pursue, to conduct detailed discussions on educational strategies, such as question techniques, predicting student responses, judging the lesson plan, and evaluating their efforts (Sims \& Walsh, 2008; Matthews et al., 2009). In addition, the lesson study encourages feedback, cooperative reflection among preservice teachers, focuses on student learning and supports the continuing professional development of teachers (McMahon \& Hines, 2008; Parks, 2008; Post \& Varoz, 2008; Rekalidou et al., 2014; Leavy \& Hourigan, 2016; Wessels, 2018). The mobilization of preservice teachers in achieving specific goals and improving their performance through the lesson study is also confirmed by other researchers in international and Greek literature (Stepanek et al., 2007; Rekalidou, 2012).

Regarding the attitudes and beliefs of preservice teachers and their trainers about the contribution of the lesson study to improving the effectiveness of internship (second research question), several studies have been identified internationally (Sims and Walsh, 2008; Matthews et al., 2009; Burroughs \& Luebeck, 2010; Cajkler et al., 2013; Carroll, 2013; Leavy \& Hourigan, 2016; Espinoza et al., 2018) in various courses, such as Mathematics, Science, Chemistry, Geography and Modern Languages and only one in Greece in Physical Education (Dania et al., 2013). Research results show that the lesson study helps preservice teachers to recognize the value of co-operation, to become more cooperative in the design of their teaching, to develop the ability to observe and collect important data on student learning and they are more open and honest in their lessons (Sims \& Walsh, 2008; Matthews et al., 2009; Carrier, 2011; Carroll, 2013; Lucas, 2014). Also, the lesson study can help improve teachers' teaching abilities (Espinoza et al., 2018).

In addition, regarding the attitudes and beliefs for the lesson study of teacher educators in higher education, a smaller number of researches were examined internationally in Mathematics (Post \& Varoz, 2008; Saito et al., 2008), Physics, Chemistry and Biology (Saito et al., 2008) and Geography and Modern Languages (Cajkler et al., 2013). Also, it is worth noting that Greece has not studied any research. The results of the study show that educators dealing with practical training, develop new ideas for preservice teacher education and co-operation through their participation in the lesson study (Post \& Varoz, 2008). They also use teamwork in their lessons, increasing student interest in learning and developing closer relationships with them. In spite of the emphasis on the importance of observing the learning reality of students, the teaching staff focuses on teaching methodology and enriches its experience and learning (Saito et al., 2008; Cajkler et al., 2013). The development of more positive beliefs and attitudes of preservice teachers and their trainers as a result of the implementation of the lesson study is demonstrated by other researchers (Lewis \& Hurd, 2011; Darling-Hammond \& Richardson, 2009).

\section{Conclusions}

From the review of the last decade researches studied, results an average 2.4 per year with most of them being conducted in the US, while few in Greece.

In particular, as far as mobilizing preservice teachers in achieving specific goals and improving their performance is concerned, it results from their experience in the lesson study, which enables them to analyze their lessons on the basis of the learning objectives pursued, conduct detailed discussions on educational strategies such as question techniques, predicting student responses, judging the lesson plan and assessing their effort. It also appears that for this particular topic in higher education a small number of researches were found internationally and limited to the subjects of Mathematics, Science, Physics, Biology and English as a foreign language, whereas in Greece two researches were studied in the framework of the Teaching Practice of preservice teachers and the Project method. As a consequence, there is a need for further investigation into more teaching subjects internationally and in Greece.

Regarding the attitudes and beliefs of preservice teachers for the lesson study, a few researches were found internationally, mainly in Mathematics and less in Science, Chemistry, Geography and Modern Languages. In Greece, only one research was found in the Physical Education course. Also, regarding the attitudes and beliefs of teacher trainers in higher education, the number of investigations is much smaller, while in Greece no research was identified. Therefore, there is a need for greater investigation of this issue in Greece and internationally. 
Moreover, from the researches examined, the formation of more positive beliefs and attitudes of the preservice teachers and their trainers regarding the value of the cooperative planning of their teaching, the reflection and the utilization of the team work in their teaching as a result of the implementation of the lesson study is demonstrated.

\section{Restrictions}

The constraints of this research include the small number of studies under consideration, the search for specific databases, and the focus on specific subjects of the lesson study in higher education.

\section{Suggestions}

Suggestions for further research could be the theoretical and practical exploration of other subjects related to the lesson study, such as the needs of teachers for training on its implementation. Moreover, by conducting comparative researches at different levels of education in the educational system of Greece on the results of its implementation and its impact on learners and educators, valuable conclusions will be drawn on the mobilization and improvement of trainees' performance, on the attitudes and beliefs of trainees and educators, as well as on the benefits, the difficulties and the conditions for effective implementation of the lesson study.

\section{References}

Angelini, M., \& Álvarez, N. (2018). Spreading lesson study in pre-service teacher instruction. International Journal for Lesson and Learning Studies, 7(1), 23-36. https:// doi.org/10.1108/IJLLS-03-2017-0016

Burroughs, E., \& Luebeck, J. (2010). Pre-service Teachers in Mathematics Lesson Study. Montana State University. The Mathematics Enthusiast, 7, 2.

Cajkler, W., Wood, P., Norton, J., \& Pedder, D. (2013). Lesson Study: towards a collaborative approach to learning in Initial Teacher Education? Cambridge Journal of Education, 43(4), 537-554. http://dx.doi.org/10.1080/0305764X.2013.834037

Carrier, S. (2011). Implementing and Integrating Effective Teaching Strategies Including Features of Lesson Study in an Elementary Science Methods Course. The Teacher Educator, 46(2), 145-160. https://doi.org/10.1080/08878730.2011.552666

Carroll, C. (2013). Exploring the Impact of Lesson Study on the Theory-Practice Gap in Pre-service Teacher Education. Master in Education. University of Limerick.

Chassels, C., \& Melville, W. (2009). Collaborative, Reflective and Iterative Japanese Lesson Study in an Initial Teacher Education Program: Benefits and Challenges. Canadian Journal of Education, 32(4), 734-763.

Dania, A., Voutsina, I., \& Moumouri, A. (2013). The application of the Lesson Study model on the teaching practice of physical education university students. Proccedings of the International Scientific Conference eRA-8, Athens, Greece. Retrieved from https://www.researchgate.net/publication/264942210_Dania_Voutsina_Moumouri_2013_The_application_o f_the_Lesson_Study_Model_on_the_teaching_practice_of_physical_education_university_students_Prcocc edings_of_the_International_Scientific_Conference_eRA-8_

Darling-Hammond, L., \& Richardson, N. (2009). Teacher learning: What matters?. Educational Leadership, 66(5), 46-53.

Dejene, W., Bishaw, A., \& Dagnew, A. (2018). Preservice teachers' approaches to learning and their teaching approach preferences: Secondary teacher education program in focus. Cogent Education, 5, 1502396 https://doi.org/10.1080/2331186X.2018.1502396

Espinosa, A., Datukan, J., Butron, B., \&Tameta, A. (2018). Perceptions of pre-service chemistry teachers on the utilization of productive lesson study as a framework for teaching and learning. International Journal for the Scholarship of Teaching and Learning, 12, 1. https://doi.org/10.20429/ijsotl.2018.120109

Fernandez, C. (2002). Learning from Japanese approaches to professional development: the case of lesson study. Journal of Teachers Education, 53(5), 393-405. https://doi.org/10.1177/002248702237394

Fernandez, M. (2010). Investigating how and what prospective teachers learn through microteaching lesson study. Teaching and Teacher Education, 26, 351-362. https://doi.org/10.1016/j.tate.2009.09.012

Giannakidou, E., Gioftsali, K., \& Tzioras, E. (2013). The reflective action of prospective teachers when implementing an appied version of the Lesson Study model. Hellenic Journal of Research in Education, 1, 30-58. Retrieved from https://ejournals.epublishing.ekt.gr/index.php/hjre/article/view/8791/9012 
Gordon, C., \& Debus, R. (2002). Developing deep learning approaches and personal teaching efficacy within a preservice teacher education context. British Journal of Educational Psychology, 72, 483-511. https://doi.org/10.1348/00070990260377488

Hamzeh, F. (2014). Lesson Study-Building Communities of Learning Among Pre-Service Science Teachers. Electronic Theses and Dissertations. 5114. Retrieved from https://scholar.uwindsor.ca/etd/5114

Hiebert, J., Morris, A., \& Glass, B. (2003). Learning to learn to teach: An 'experiment' model for teaching and teacher preparation in mathematics. Journal of Mathematics Teacher Education, 6, 201-222. https://doi.org/10.1023/A:1025162108648

Juhler, M. (2018). Pre-service teachers' reflections on teaching a physics lesson: How does Lesson Study and Content Representation affect pre-service teachers' potential to start developing PCK during reflections on a physics lesson. NORDINA, 14(1), 22-36. https://doi.org/10.5617/nordina.2433

Leavy, A., \& Hourigan, M. (2016). Using lesson study to support knowledge development in initial teacher education: Insights from early number classrooms. Teaching and Teacher Education, 57, 161-175. https://doi.org/10.1016/j.tate.2016.04.002

Lenski, S., Caskey, M., \& Anfara, V. (2009). Using the Lesson Study Approach to Plan for Student Learning. Middle School Journal, 40(3), 50-57. https://doi.org/10.1080/00940771.2009.11495587

Lewis, C., \& Hurd, J. (2011). Lesson Study step by step. How Teacher Learning Communities Improve Instruction. Portsmouth, NH, USA.

Lewis, C., Perry, R., \& Hurd, J. (2004). A deeper look at lesson study. Educational Leadership, 61(5), 18-23.

Lewis, C., \& Tsuchida, I. (1998). A lesson is like a swiftly flowing river: Research lessons and the improvement of Japanese education. American Educator, 14-17, 50-52.

Lucas, M. (2014). Lesson Study, a Means for Fostering Collaborative Reflection: Effects on the Self-Efficacy and Teaching Practices of Developmental Education College Success Course Instructors. Dissertation, Arizona State University.

Matthews, M., Hlas, C., \& Finken, T. (2009). Using Lesson Study and Four-Column Lesson Planning with Preservice Teachers. Mathematics Teacher, 102(7), 504-508.

McMahon, M., \& Hines, E. (2008). Lesson Study with Preservice Teachers. Mathematics Teacher, 102(3), 186-191.

Molina, R. (2012). Microteaching Lesson Study: Mentor Interaction Structure and its Relation to Elementary Preservice Mathematics Teacher Knowledge Development. FIU Electronic Theses and Dissertations. 616.

Nishimura, K. (2016). Lesson study at the upper secondary level in Japan. In Presentation, Lesson Study Mini Conference. Nottingham, UK.

Parks, A. (2008). Messy learning: Preservice teachers' lesson study conversations about mathematics and students. Teaching and Teacher Education, 24(5), 1200-1216. https://doi.org/10.1016/j.tate.2007.04.003

Pongsanon, K., Akerson, V., Rogers, M., \& Weiland, I. (2011). Exploring the Use of Lesson Study to Develop Elementary Preservice Teachers ' Pedagogical Content Knowledge for Teaching Nature of Science. Paper presented at the National Association for Research in Science Teaching. Orlando, Florida.

Post, G., \& Varoz, S. (2008). Lesson-Study Groups with Prospective and Practicing Teachers. Teaching Children Mathematics, 14(8), 472-478.

Rekalidou, G. (2012). Improving teaching. The case of Lesson Study. Pedagogy-Theory and Practice, 5, 98-109. Retrieved from http://www.pedagogy.gr/images/tefxoi/teuxos5.pdf

Rekalidou, G., Moumoulidou M., Karadimitriou, K., Mavrommatis, G., \& Salmont, E. (2013). Pilot implementation of the Lesson Study model in the Preschool Education Students Practicum Program. Practical training in initial teacher education: Research approaches. In A. Androusou, \& S. Avgetidou (Eds.), Practice Exercise Network, Department of Early Childhood Education (pp. 69-95). National and Kapodistrian University, Athens.

Rekalidou, G., Karadimitriou, K., \& Moumoulidou, M. (2014). Implementation of Lesson Study with students. Collaboration, reflection and feedback. Hellenic Journal of Research in Education, Improving the Education of Future Teachers in Crisis of Institutions: Proposals, Applications. Alexandroupolis, May 2014, 7-28. 
Saito, E., Hawe, P., Hadiprawiroc, S., \& Empedhe, S. (2008). Initiating education reform through lesson study at a university in Indonesia. Educational Action Research, 16(3), 391-406. https://doi.org/10.1080/09650790802260372

Saito, E. (2012). Key issues of lesson study in Japan and the United States: A literature review. Professional Development in Education, 38, 777-789. https://doi.org/10.1080/19415257.2012.668857

Sims, L., \& Walsh, D. (2009). Lesson Study with preservice teachers: Lessons from lessons. Teaching and Teacher Education, 25, 724-733. https://doi.org/10.1016/j.tate.2008.10.005

Stepanek, J., Appel, G., Leong, M., Turner Mangan, M., \& Mitchell, M. (2007). Leading Lesson Study. A practical guide for teachers and facilitators. California, USA.

Wessels, H. (2018). Noticing in Pre-service Teacher Education: Research Lessons as a Context for Reflection on Learners' Mathematical Reasoning and Sense-Making. In G. Kaiser et al. (Eds.), Invited Lectures from the 13th International Congress on Mathematical Education. ICME-13 Monographs.

https://doi.org/10.1007/978-3-319-72170-5_41

\section{Copyrights}

Copyright for this article is retained by the author(s), with first publication rights granted to the journal.

This is an open-access article distributed under the terms and conditions of the Creative Commons Attribution license (http://creativecommons.org/licenses/by/4.0/). 